\title{
Pengaruh Harga Diri Terhadap Perilaku Social Climber Pada Mahasiswa Bimbingan dan Konseling Universitas Negeri Semarang
}

\author{
Iin Musafa'ah \\ Universitas Negeri Semarang, Jawa Tengah, Indonesia \\ iinmusafaah14@gmail.com \\ Sugiyo \\ Universitas Negeri Semarang, Jawa Tengah, Indonesia
}

sgy11@mail.unnes.ac.id

\begin{abstract}
Abstrak
Penelitian ini memiliki tujuan untuk mengetahui pengaruh antara harga diri terhadap perilaku social climber pada mahasiswa Bimbingan dan Konseling Universitas Negeri Semarang. Fenomenafenomena tersebut berhubungan dengan perilaku social climber. Perilaku social climber pada mahasiswa ini paling menonjol dapat dilihat dari lifestylenya seperti penampilan dan pergaulannya. Hal ini dapat terjadi karena adanya keinginan untuk memperoleh pengakuan dari orang-orang di sekitarnya. Metode yang digunakan dalam penelitian ini adalah metode kuantitatif yang menggunakan sebuah alat pengumpul data yaitu skala pikologis. Hasil penelitian ini adalah terdapat hubungan yang signifikan antara harga diri terhadap perilaku social climber. Hasil penelitian ini juga bermanfaat bagi guru BK (Konselor) agar lebih memberikan inovasi dalam malakukan layanan Bimbingan dan Konseling, khususnya agar mampu membimbing individu dengan perilaku social climber untuk menjadi pribadi yang mau menerima dirinya secara apa adanya.
\end{abstract}

Kata kunci: Harga Diri, Lifestyle, Perilaku Social Climber

\section{Abstract}

The Effect of Self-Esteem on Social Climber Behavior in Guidance and Counseling Students, Semarang State University. This study 
aims at examining the influence of self-esteem on social climber behavior on Guidance and Counseling students at Universitas Negeri Semarang. These phenomena were related to the behavior of social climber. The most highlighted social climber behavior on students reflected in their lifestyle, e.g. their appearance and circle. This phenomenon happened because of the desire to get recognition from the surroundings. The research was a quantitative method using a psychological scale to collect the data. The results of this study showed that there was a significant relationship between self-esteem and social climber behavior on students. The results of this study are useful for Guidance and Counseling teachers to provide more innovation in conducting Guidance and Counseling services, especially in order to be able to guide individuals with social climber behavior to become individuals who want to accept themselves as they are.

Keywords: Self-Esteem, Lifestyle, Social Climber Behavior

\section{A. Pendahuluan}

Perkembangan era modern saat ini, perilaku individu perlu mendapatkan perhatian khusus agar individu berperilaku sesuai dengan nilai dan norma yang berlaku di masyarakat. Sehingga perlu dilakukannya bimbingan pribadi, baik pada individu yang sudah berperilaku menyimpang maupun belum berperilaku menyimpang sebagai pencegahan. Kehidupan di kota metropolitan Semarang, tentu akan memberikan dampak pada pola dan gaya hidup serta perilaku individu. Di kota ini banyak dijumpai swalayan yang berdiri dengan megah serta tempat makan dan nongkrong yang terkenal di kalangan masyarakat. Bagi individu yang tidak puas dengan status sosialnya tersebut akan melakukan manipulasi keadaan yang sebenarnya yang mana ini disebut sebagai perilaku social climber. Social climber merupakan salah satu perilaku yang menyimpang di dalam kehidupan sosial masyarakat dan perlu dilakukannya bimbingan pribadi pada pelakunya.

Social climber merupakan individu yang berusaha mendapatkan pengakuan status yang lebih tinggi dengan memanipulasi keadaaan agar dianggap orang kaya raya (Nurudin, 2017:228). Hal ini ditunjukkan dengan individu yang dalam kesehariannya menggunakan barang-barang branded serta berkumpul di tempat- 
tempat yang sekiranya terkenal di masyarakat. Sebagaimana disebutkan Jayanti (2015:7) bahwa karakteristik social climber salah satunya adalah memiliki kebutuhan yang harus dipenuhi, khususnya dalam dunia lifestyle. Jadi dari pengertian beberapa pakar dapat disimpulkan bahwa Social Climber merupakan perilaku memanipulasi keadaan demi mendapatkan pengakuan status sosialnya. Hal inilah yang menjadikan bahwa cara yang ditempuh seorang individu untuk memperoleh pengakuan yang lebih tinggi adalah cara negatif. Kalangan mahasiswa dapat menjadi salah satu tempat banyak dijumpainya perilaku social climber. Dimana mereka hidup berada jauh dari orang tua, sehingga untuk kontrol dari orang tua tentunya berkurang. Dan apabila dilihat dari segi financial tentu lebih tinggi dari anak-anak sekolah menengah. Selain itu, dilihat dari pergaulannya tentu sangat luas. Dan yang pasti dalam pergaulannya tersebut tentunya banyak dijumpai individu-individu yang memang berasal dari status sosial yang menengah ke atas.

Terdapat beberapa faktor yang mempengaruhi perilaku social climber tersebut. Menurut Kembau (2015:2-5) perilaku social climber diperngaruhi oleh pertumbuhan ekonomi negara, lingkungan sosial individu (kelompok pertemanan yang dia ikuti, gaya hidup keluarga serta peran dan status-nya di masyarakat), dan kebutuhan psikologis (affiliations needs, esteem needs dan self-actualization). Sedangkan Artika (2010:2) menyebutkan bahwa konstruksi pemikiran pelaku social climber terbentuk karena setiap orang memiliki motif sosiogenis yang berarti bahwa karena adanya lingkungan sosial, muncul kebutuhan yang harus dipenuhi untuk dapat mempertahankan hubungan dengan orang lain dan lingkungan sosialnya. Berada di budaya yang baru bisa menjadi salah satu faktor yang mendorong seseorang atau kelompok untuk melakukan perubahan sosial. Kontak dengan kebudayaan luar di era globalisasi seperti saat ini menjadi salah satu alasan mengapa social climber membutuhkan gaya hidup yang lebih tinggi dibandingkan dengan individu atau kelompok lain. Selain beradaptasi dengan gaya hidup yang lebih tinggi, individu sendiri mulai membandingkan dan menginginkan hal yang tidak di dapatkannya dari situasi mereka sebelumnya. Jadi dapat 
disimpulkan bahwa perilaku social climber menurut Artika dipengaruhi oleh budaya dan pengalaman masa lalu.

Dari kedua pendapat tersebut sangat jelas menunjukkan adanya perbedaan faktor yang mempengaruhi perilaku social climber. Untuk itu peneliti bermaksud untuk membuktikan ada tidaknya pengaruh self-esteem (harga diri) terhadap perilaku social climber. Penelitian ini bermanfaat bagi guru BK/Konselor agar lebih memberikan inovasi dalam melakukan layanan BK, khususnya agar mampu membimbing individu dengan perilaku social climber untuk menjadi pribadi yang mau menerima dirinya secara apa adanya.

\section{B. Metode}

Dalam metode penelitian akan diuraikan mengenai: (1) jenis penelitian, (2) variabel penelitian, (3) populasi dan sampel, (4) metode dan alat pengumpulan data dan (5) Hasil uji validitas dan reliabilitas, (6) hasil penelitian. Berikut uraiannya yaitu:

1. Jenis Penelitian

Dalam penelitian ini, peneliti menggunakan jenis penelitian kuantitatif kolerasional. Menurut Arikunto (2010) jenis penelitian kuantitatif kolerasional adalah penelitian yang digunakan untuk menganalisis ada tidaknya hubungan antara dua variabel atau lebih. Peneliti menggunakan jenis penelitian kuantitatif kolerasional karena peneliti memiliki tujuan untuk mengetahui pengaruh antara harga diri terhadap perilaku social climber pada mahasiswa Bimbingan dan Konseling Universitas Negeri Semarang.

2. Variabel Penelitian

Variabel merupakan gejala yang menjadi fokus peneliti untuk diamati sehinnga diperoleh informasi kemudian ditarik kesimpulannya (Sugiyono, 2017:60). Dalam penelitian ini melibatkan dua jenis variabel yaitu variabel independen dan dependen. Sehingga variabel independen (bebas) dalam 
penelitian ini adalah harga diri, sedangkan variabel dependen (terikat) adalah perilaku social climber.

3. Populasi dan Sampel

Populasi dalam penelitian ini adalah mahasiswa Bimbingan dan Konselin Universitas Negeri Semarang mulai dari angkatan 2015 sampai 2018 dengan jumlah 342 orang. Teknik pengambilan sampel dalam penelitian ini menggunakan propotionate stratified random sampling, yaitu pengambilan anggota sampel dari populasi yang memiliki anggota yang tidak homogen (heterogen) dan berstrata secara proporsional (Sugiyono, 2017:120). Dalam hal ini, populasi yang digunakan berjumlah 342 dengan taraf kesalahan 5\%, maka jumlah sampel yang digunakan berjumlah 172 orang.

4. Metode dan Alat Pengumpul Data

Metode pengumpul data merupakan salah satu tahap sistematis yang harus dilalui oleh peneliti dalam memperoleh informasi penting yang dibutuhkan sebagai bahan penelitian. Dalam penelitian ini, peneliti menggunakan metode pengumpul data yang mengukur aspek psikologi atau biasa disebut skala psikologis. Skala psikologis digunakan untuk mengungkap keadaan psikologis dari aspek kepribadian individu. Dalam penelitian ini skala psikologi digunakan untuk mengukur harga diri dan perilaku social climber. Sehingga alat pengumpul data yang digunakan yaitu skala harga diri dan perilaku social climber. Berikut akan diuraikan mengenai kisi-kisi intrumen setiap skala, yaitu:

Tabel 4.1

Kisi-Kisi Instrumen Skala Perilaku Social Climber

\begin{tabular}{|c|c|c|c|c|}
\hline \multirow{2}{*}{ No } & \multirow{2}{*}{ Indikator } & \multicolumn{2}{|c|}{ Nomor Item } & \multirow{2}{*}{ Jumlah } \\
\hline & & $(+)$ & $(-)$ & \\
\hline 1. & Penampilan & $1,2,5,6,7$ & $3,4,8,9$ & 9 \\
\hline 2. & Pergaulan & $\begin{array}{c}10,11,14,16,18,19 \\
22,23,25,27,28\end{array}$ & $\begin{array}{c}12,13,15,17,20,21 \\
24,26,29,30\end{array}$ & 21 \\
\hline 3. & Pendidikan & 31,32 & 33 & 3 \\
\hline
\end{tabular}


Pengaruh Harga Diri Terhadap Perilaku ...

\begin{tabular}{rcccc}
\hline 4. & Pribadi & $34,35,38,39$ & $36,37,40$ & 7 \\
\hline Total & 22 & 18 & 40 \\
\hline
\end{tabular}

Tabel 4.2

Kisi-Kisi Instrumen Harga Diri

\begin{tabular}{|c|c|c|c|c|}
\hline \multirow{2}{*}{ No } & \multirow{2}{*}{ Indikator } & \multicolumn{2}{|c|}{ Nomor Item } & \multirow{2}{*}{ Jumlah } \\
\hline & & $(+)$ & $(-)$ & \\
\hline & Mandiri & 1,3 & 2,4 & 4 \\
\hline 2. & $\begin{array}{l}\text { Bertanggung } \\
\text { jawab }\end{array}$ & $5,7,8$ & $6,9,10$ & 6 \\
\hline 3. & $\begin{array}{l}\text { Bangga terhadap } \\
\text { kemajuan } \\
\text { dirinya }\end{array}$ & 11,12 & 13,14 & 4 \\
\hline & $\begin{array}{l}\text { Mampu } \\
\text { menghadapi } \\
\text { kegagalan }\end{array}$ & $15,16,17$ & $18,19,20$ & 6 \\
\hline 5. & $\begin{array}{l}\text { Mampu } \\
\text { Menghargai diri } \\
\text { sendiri }\end{array}$ & $\begin{array}{c}21,22,24,25,29 \\
30\end{array}$ & $\begin{array}{c}23,26,27,28,31, \\
32\end{array}$ & 12 \\
\hline 6. & $\begin{array}{l}\text { Disenangi } \\
\text { banyak orang }\end{array}$ & $33,34,35,38,39$ & $36,37,40$ & 8 \\
\hline Total & & 21 & 19 & 40 \\
\hline
\end{tabular}

5. Uji Validitas dan Reliabilitas

Instrumen diatas dijadikan sebagai pedoman saat melakukan uji coba penelitian dengan sampel 50 mahasiswa. Dalam perhitungan menggunakan SPSS 25 untuk uji validitas akan melihat rtabel dari $\mathrm{N}=50$ yaitu 0,279 . Item dalam instrumen dinyatakan valid ketika koefisien validitasnya $>0,279$. Berdasarkan hasil perhitungan, ada beberapa item yang dinyatakan tidak valid sehingga item tersebut harus gugur.

Penelitian yang baik harus memiliki instrument penelitian yang valid dan reliabel. Uji reliabilitas juga menggunakan bantuan SPSS 25 dan diperoleh hasil sebagai berikut : 


\section{Tabel 4.4}

Keputusan Hasil Uji Reabilitas

\begin{tabular}{cccc}
\hline Skala & r hitung & $\begin{array}{c}\mathbf{r} \text { tabel 5\% } \\
(\mathbf{n = 5 0 )}\end{array}$ & Keterangan \\
\hline Social Climber $(\mathrm{Y})$ & 0,745 & 0,279 & Reliabel \\
\hline Harga Diri $(\mathrm{X})$ & 0,834 & 0,279 & Reliabel \\
\hline
\end{tabular}

\section{Pembahasan}

Dalam pembasahan ini akan diuraikan penjelaskan mengenai pokok bahasan dari penelitian ini yaitu perilaku social climber dan harga diri. Metode penelitian juga akan dijelaskan pada bab ini. Berikut uraian dari pokok pembahasan dalam penelitian ini:

\section{Perilaku Social Climber}

a. Pengertian Social Climber

Social climber berasal dari kata social climbing (mobilitas sosial vertikal naik) yang memiliki pengertian yaitu perpindahan kedudukan sosial seseorang atau kelompok anggota masyarakat dari lapisan sosial rendah ke lapisan sosial yang lebih tinggi dalam masyarakat, karena adanya peningkatan prestasi atas diri seseorang maupun peningkatan prestasi kerja yang dilakukan oleh seseorang tersebut (Soekanto, 2013:220).

Menurut Permatasari (2017:17) mengatakan bahwa social climber adalah sesorang yang menginginkan pengakuan yang lebih tinggi dari yang sebenarnya terhadap status sosialnya. Sedangkan Pembayun (2018:41) juga mengatakan bahwa social climber merupakan usaha yang mampu membantu seseorang untuk memperoleh penerimaan dan juga posisi yang tentunya lebih baik dalam bersosialisasi.

Dari beberapa pendapat tersebut, maka dapat ditarik kesimpulan bahwa social climber merupakan proses yang dilakukan seseorang untuk memperoleh pengakuan dari lingkungan sosialnya, melalui usaha-usaha 
baik positif maupun negatif yang dapat meningkatkan status sosialnya pada tingkatan yang lebih tinggi dari sebelumnya.

b. Karakteristik Perilaku Social Climber

Karakteristik merupakan ciri-ciri yang dapat menandakan bahwa seseorang memiliki perilaku social climber. Menurut Jayanti (2015:7) karakteristik social climber meliputi :

1) Memiliki kebutuhan yang harus dipenuhi. Seorang social climber akan senantiasa berusaha untuk mengikuti perkembangan trend dunia lifestyle. Hays (2012:1) mengatakan "Consumers purchase expensive clothing, cars, and other goods to signal their standing in society's status hierarchy." Jadi pakaian, mobil, dan barang-barang mahal sebagai tanda kedudukan mereka dalam status sosial di masyarakat.

2) Berada di budaya yang baru. Budaya baru salah satunya dapat digambarkan dalam dunia kuliah. Dimana di dunia perkuliahan akan lebih banyak dijumpai orang-orang baru yang tentunya berasal dari berbagai budaya serta golongan sosial yang berbeda-beda. Lestari (2017:12) menyatakan bahwa individu yang berada dalam budaya baru secara perlahan akan membandingkan dan mulai menginginkan hal-hal yang tidak ia peroleh dari keadaan atau budaya mereka sebelumnya. Bagi mereka yang tidak puas dengan status sosialnya akan semakin terlihat dan akan menggunakan segala cara untuk bisa merubah status sosialnya (Permatasari. 2017:16).

3) Membutuhkan gaya hidup yang lebih tinggi dari sebelumnya. Gaya hidup merupakan pola hidup seseorang yang diekpresikan melalui aktivitas, minat, serta opininya (Lestari, 2017:11). Dunia perkuliahan, yang sejatinya dapat ditemui orang-orang dari berbagai golongan, pun tidak sedikit yang berasal dari kalangan menengah ke atas. Sehingga menuntut individu agar memiliki gaya hidup sebagaimana lingkungan sekitarnya. Hal ini yang akhirnya menjadikan individu untuk memiliki gaya hidup lebih tinggi dari sebelumnya. 
4) Memiliki hasrat, harapan, dan kehidupan yang lebih tinggi. Mengikuti gaya hidup yang mewah tentu tidak semata-mata karena kemauan diri sendiri. Tentunya seorang social climber memiliki harapan agar dapat diterima dalam kelompok sosialnya.

5) Menciptakan dunia, struktur sosial, termasuk simbol dan proses komunikasinya sendiri. Pelaku social climber dalam mengkontruksikan status sosialnya melalui apa yang mereka kenakan dan yang melekat pada dirinya (Permatasari, 2017:71). Memposting aktivitas bila berada di suatu tempat yang ramai dikunjungi oleh orang-orang yang berada di kelas sosial menengah ke atas, juga merupakan simbol dan proses komunikasi yang dilakukan oleh pelaku social climber.

6) Memiliki target ideal. Target ideal social climber adalah main role (pemeran utama) dalam kelompok mereka yang selalu menjadi panutan bagi mereka (Jayanti, 2015:7). Jadi dalam pergaulan social climber, tentu terdapat pemeran utama dimana ia menjadi panutan atau model yang harus ditiru oleh individu lainnya, baik dari cara berpakaian, berkomunikasi, maupun pergaulan.

7) Motivasi untuk meningkatkan status sosial. Motivasi merupakan dorongan dalam diri individu guna mencapai suatu tujuan tertentu. Seorang social climber memiliki motivasi untuk mempertahankan posisinya dalam kelompok sehingga kehadirannya dapat selalu diterima dan tidak dikucilkan (Jayanti, 2015:7).

c. Faktor-Faktor yang Mempengaruhi Perilaku Social Climber

Terdapat beberapa faktor yang mempengaruhi perilaku social climber tersebut. Menurut Kembau (2015:2-5) faktor yang memperngaruhi perilaku social climber meliputi :

Pertama, pertumbuhan ekonomi negara. Kembau (2015:2) menyatakan "pertumbuhan ekonomi Indonesia dalam kurun dekade terakhir memberikan berdampak pada peningkatan daya beli masyarakat". 
Hal tersebut terjadi karena apabila pertumbuhan ekonomi suatu negara semakin meningkat, maka penghasilan yang diperoleh oleh masyarakat pun ikut meningkat. Sehingga dengan penghasilan yang lebih tersebut akan mendorong masyarakat untuk membeli barang-barang yang diinginkannya bukan lagi yang dibutuhkan.

Kedua, lingkungan sosial individu. Lingkungan sosial ini meliputi kelompok pertemanan yang diikuti, keluarga, serta statusnya di masyarakat. Ketika individu berada dalam kelompok pertemanan atau keluarga yang berisi orang-orang dari kelas sosial menengah ke atas, maka individu tersebut akan berusaha mengikuti dan mengimbangi pola hidup orang yang ada dalam kelompok tersebut. Selanjutnya ada gaya hidup keluarga, serta peran dan status-nya di masyarakat.

Ketiga, adanya kebutuhan psikologis. Apabila kebutuhan fisiologis manusia yaitu sandang, pangan, dan kesehatan telah terpenuhi, manusia cenderung akan mencari kebutuhan pada tingkat selanjutnya seperti affiliations needs (kebutuhan sosial), esteem needs dan self-actualization dimana semua tingkatan kebutuhan tersebut mengarah kepada kebutuhan psikologis, tentang rasa ingin dicintai, diterima, dihormati dan didengar dari orang-orang disekitarnya, menurut Maslow dalam Jarvis (2018:94-95).

\section{Harga Diri}

a. Pengertian Harga Diri

Coopersmith dalam Wangge (2013:3) mendefinisikan harga diri sebagai evaluasi yang dibuat oleh individu mengenai dirinya sendiri, dimana evaluasi diri tersebut merupakan hasil interaksi antara individu dengan lingkungannya serta perlakuan orang lain terhadap dirinya. Secara singkat Rogers dalam Jarvis (2011:343) Self esteem (harga diri) didefinisikan sebagai seberapa besar kita menyukai diri kita sendiri.

Rosenberg dalam Martin (2007:459) mengungkapkan bahwa harga diri merupakan komponen dari konsep diri dan didefinisikan sebagai sebuah pengaturan terhadap pemikiran dan perasaan individu tentang nilai 
dan pentingnya diri sendiri yaitu sikap positif atau negatif yang menyeluruh terhadap diri sendiri. Sedangkan Badri (2011:34) menyimpulkan bahwa harga diri adalah penilaian seseorang terhadap keberhargaan dirinya baik secara fisik, intelektual, emosional, maupun moral yang diperoleh dari hasil interaksinya dengan lingkungannya dan penghargaan, penerimaan serta perlakuan orang lain terhadap dirinya.

Dari berbagai pendapat tersebut, maka dapat disimpulkan bahwa harga diri merupakan suatu evaluasi atau penilaian secara menyeluruh pada diri, yang dilakukan seseorang terhadap dirinya sendiri. Sehingga dari evaluasi tersebut maka diperoleh rasa puas maupun tidak puas terhadap apa yang telah dialami maupun dilakukan.

b. Aspek-Aspek Harga Diri

Aspek-aspek harga diri menurut Coopersmith dalam Sandha (2012:58) menyebutkan terdapat 4 aspek, antara lain :

\section{1) Kekuasaan (power)}

Kekuasaan ini merupakan sebuah kemampuan yang digunakan atau dilakukan oleh individu untuk mengatur serta memberikan pengaruh kepada orang lain yaitu dengan tujuan agar ia dapat memperoleh pengakuan serta rasa hormat dari orang lain.

2) Keberartian (significance)

Keberartian ini meliputi penerimaan, perhatian, serta afeksi yang diterima oleh seorang individu. Semakin banyak seorang individu itu memperoleh penerimaan, perhatian, serta afeksi maka ia akan semakin merasa bahwa keberadaannya sangat berarti bagi orang lain atau orang disekitarnya. Serta sebaliknya apabila yang terjadi adalah kurangnya penerimaan, perhatian, dan afeksi maka ia akan merasa bahwa dirinya tidak berarti bagi orang lain disekitarnya.

3) Kebajikan (virtue)

Kebajikan disini yaitu dimaksudkan suatu ketaatan yang dimiliki individu terhadap standar nilai-nilai moral dan etika yang berlaku di 
lingkungannya. Seorang individu akan berusaha untuk menghindari hal-hal atau perilaku yang tidak diperbolehkan serta melakukan halhal yang diperbolehkan atau diharuskan oleh nilai-nilai moral, etika, dan agama yang berlaku di lingkungannya. Jadi dengan kata lain kemampuan yang dimaksud adalah kemampuan untuk melakukan hal-hal yang diperbolehkan dan tidak melakukan hal-hal yang tidak boleh dilakukan sesuai dengan nilai-nilai yang dianut oleh masyarakat.

\section{4) Kemampuan (competence)}

Sebagaimana yang dimaksud oleh Wahdania (2017:73) bahwa kompetensi merupakan kemampuan individu bahwa dirinya merasa mampu dan memiliki sikap optimis dalam menghadapi masalah kehidupan serta mampu mencapai tujuan hidupnya secara efisien. Begitupun dengan Sandha (2012:57) ia menjelaskan bahwa kompetensi ini menunjukkan adanya suatu kemampuan terbaik yang dimiliki individu dalam meraih tujuan untuk memenuhi tuntutan prestasi.

\section{c. Harga Diri Tinggi}

Individu dengan harga diri yang tinggi adalah individu yang puas atas karakter dan kemampuan dirinya (Widodo, 2013:133). Jadi dapat dijelaskan bahwa, harga diri yang dimiliki seorang individu dikatakan tinggi apabila ia memiliki pandangan yang positif terhadap dirinya serta mampu menerima dirinya dengan apa adanya

Menurut Fitra (2015:13-14) menyebutkan terdapat beberapa ciri bahwa seorang individu memiliki harga diri yang tinggi, meliputi: (1) Merasa bahwa dirinya berharga, (2) Merasa banyak hal-hal baik yang dimiliki, (3) Percaya dengan kemampuan yang dimiliki, (4) Dapat menghormati apa adanya dirinya sendiri, (5) Memiliki sikap yang positif terhadap berbagai hal, dan tidak memiliki sikap sombong, (6) Merasa puas dengan diri sendiri. 


\section{d. Harga Diri Rendah}

Harga diri rendah adalah suatu evaluasi diri yang negatif dan berhubungan dengan perasaan yang lemah, tidak berdaya, ketakutan, tidak berharga, dan tidak memadai (World dalam Narullita, 2017:355). Sedangkan Widodo (2013:134) bependapat bahwa individu dengan harga diri yang rendah adalah individu yang hilang kepercayaan diri dan tidak mampu menilai kemampuan diri. Salah satu cara meningkatkan harga diri adalah dengan bimbingan dan konseling. Karena, tujuan bimbingan dan konseling adalah untuk mengembangkan potensi pada individu seoptimal mungkin, sesuai dengan kemampuan agar bisa menyesuaikan diri dengan lingkungannya, baik lingkungan sekolah, keluarga maupun lingkungan masyarakat (Bastomi, 2020).

Menurut Yusuf \& Nurihsan dalam Bastomi (2019) Proses Bimbingan dan Konseling di sekolah dapat berhasil apabila mempunyai tujuan yang jelas yang akan dicapainya. Bimbingan dan konseling bertujuan untuk membantu peserta didik agar dapat mencapai tujuan-tujuan perkembangannya yang meliputi aspek pribadi-sosial belajar (akademik) dan karir. Sedangkan tujuan bimbingan dan konseling Islam menurut Mubarok dalam Bastomi (2017) Secara singkat dapat dirumuskan sebagai berikut : (1) Tujuan umum Konseling Islam untuk membantu konseli agar dia memiliki pengetahuan tentang posisi dirinya dan memiliki keberanian mengambil keputusan, untuk melakukan suatu perbuatan yang dipandang baik, benar dan bermanfaat, untuk kehidupannya di dunia dan untuk kepentingan akhiratnya. (2) Tujuan khusus bimbingan konseling Islam adalah: (a) Untuk membantu konseli agar tidak menghadapi masalah. (b) Untuk membantu konseli mengatasi masalah yang sedang dihadapinya. (c) Untuk membantu konseli memelihara dan mengembangkan situasi dan kondisi yang baik atau yang telah baik agar tetap baik, sehingga tidak akan menjadi sumber masalah bagi dirinya dan orang lain.

Menurut Gea dalam Asytharika (2016:34) ciri-ciri orang yang self esteem rendah antara lain: (1) Menuntut cinta dan kekaguman terlalu 
banyak dari orang lain, (2) Gila kesempatan dan berharap terlalu banyak pada dirinya, (3) Terlalu takut mengalami kekalahan dan kegagalan, (4) Terlalu dihantui kesuksesan orang lain, (5) Menghindari tanggung jawab dengan menyatakan telah gagal, (6) Terlalu peka perasaan.

e. Faktor-Faktor yang Mempengaruhi Harga Diri

Salamiah (2011:67-68) mengemukakan bahwa harga diri dipengaruhi oleh:

1) Pola Asuh Orang tua

Orang tua menjadi faktor penyebab tinggi rendahnya harga diri karena orang tua merupakan sumber pertama pengalaman yang diperoleh seorang individu. Hubungan orang tua dan anak dapat diwujudkan dalam bentuk penerimaan, permitif, demokratis dan latihan kebebasan. Dimana semua yang disebutkan tersebut merupakan bentuk dari pola asuh, dan setiap pola asuh yang dilakukan atau digunakan tidak hanya berpengaruh pada perkembangan anak akan tetapi juga pada harga dirinya.

2) Kemampuan Umum

Kemampuan umum ini dapat diketahui dari tingkat IQ. Berdasarkan hasil penelitian Dewit dan Kollanda (2004) sebagaimana dikutip oleh Salamiah menyebutkan bahwa individu yang memiliki IQ tinggi mengalami perubahaan positif dalam harga dirinya, sedangkan individu yang memiliki IQ rendah memiliki pengaruh yang negatif terhadap harga dirinya.

3) Keadaan Fisik

Individu akan memiliki perhatian yang besar terhadap penampilan dirinya. Ia akan berusaha untuk mengikuti perkembangan tren atau mode yang sedang berlangsung. Seorang individu akan merasa dirinya berharga apabila mereka berpakaian, berdandan, dan bertingkah laku sebagaimana orang-orang disekitarnya. Sehingga ia 
akan merasakan adanya pengakuan ataupun penerimaan atas dirinya di dalam orang-orang disekitarnya.

4) Potensi Akademik

Dalam bidang pendidikan, tentunya prestasi yang diperoleh seorang individu menjadi salah satu penilaian terhadap dirinya. Individu akan merasa bahwa dirinya berharga di sekitar teman-teman dalam pendidikannya apabila ia memiliki prestasi akademik yang baik. Namun, apabila ia merasa bahwa prestasi akademiknya kurang, individu tersebut akan cenderung merasa minder, tidak berguna, bodoh, serta yang lebih parah individu tersebut akan menutup diri.

\section{Pengaruh Harga Diri Terhadap Perilaku Social Climber Pada Mahasiswa BK UNNES}

Untuk mengetahui adanya pengaruh dan seberapa besar pengaruh antar variabel yang diteliti, menggunakan uji analisis regresi dengan menggunakan bantuan SPSS 25. Berikut akan diuraian mengenai hasil uji analisis regresi dalam bentuk tabel :

Tabel 4.5

Hasil Uji Analisis Regresi

\begin{tabular}{|c|c|c|c|c|c|c|}
\hline \multicolumn{7}{|c|}{ Coefficients $^{a}$} \\
\hline & & \multicolumn{2}{|c|}{$\begin{array}{c}\text { Unstandardized } \\
\text { Coefficients }\end{array}$} & \multirow{2}{*}{$\begin{array}{c}\text { Standardize } \\
\mathrm{d} \\
\text { Coefficients } \\
\text { Beta } \\
\end{array}$} & \multirow[b]{2}{*}{$\mathrm{t}$} & \multirow[b]{2}{*}{ Sig. } \\
\hline \multicolumn{2}{|c|}{ Model } & $\mathrm{B}$ & Std. Error & & & \\
\hline \multirow[t]{2}{*}{1} & $\begin{array}{l}\text { (Constant } \\
\text { J }\end{array}$ & 97.996 & 7.689 & & 12.746 & .000 \\
\hline & $\begin{array}{l}\text { Harga } \\
\text { Diri }\end{array}$ & .146 & .061 & .180 & 2.392 & .018 \\
\hline
\end{tabular}

a. Dependent Variable: Social Climber

Persamaan regresi sederhana adalah $\mathrm{Y}=\mathrm{a}+\mathrm{bX}$. Sehingga berdasarkan table diatas dapat diperoleh persamaan sebagai berikut: 
$\mathrm{a}=$ angka konstan dari unstandardized coefficients sebesar 97,996. Angka ini merupakan angka konstan yang mempunyai arti bahwa jika tidak ada harga diri (X) maka nilai konstan perilaku social climber (Y) sebesar 97,996.

$\mathrm{b}=$ angka koefisien regresi. Nilainya sebesar 0,146. Angka ini memberikan arti bahwa setiap penambahan $1 \%$ tingkat harga diri (X), maka perilaku social climber (Y) akan meningkat sebesar 0,146.

Karena nilai koefisien regresi bernilai positif, maka dengan demikian dapat disimpulkan bahwa Harga Diri (X) berpengaruh terhadap Perilaku Social Climber $(\mathrm{Y})$, sehingga persamaan regresinya adalah $\mathrm{Y}=97,996-0,146 \mathrm{X}$. Berdasarkan tabel di atas diketahui nilai signifikansi (Sig.) sebesar 0,018 lebih kecil dari < probabilitas 0,05. Sehingga dapat disimpulkan bahwa hipotesis diterima, yang berarti harga diri berpengaruh terhadap perilaku social climber pada mahasiswa Bimbingan dan Konseling Universitas Negeri Semarang.

Untuk mengetahui seberapa besarnya pengaruh harga diri terhadap perilaku social climber pada mahasiswa Bimbingan dan Konseling Universitas Negeri Semarang, dapat dilihat pada tabel berikut :

Tabel 4.6

Hasil Output Pengaruh Harga Diri terhadap Perilaku Social Climber

\begin{tabular}{|c|c|c|c|c|}
\hline \multicolumn{5}{|c|}{ Model Summary } \\
\hline Model & $\mathrm{R}$ & R Square & $\begin{array}{c}\text { Adjusted R } \\
\text { Square }\end{array}$ & $\begin{array}{l}\text { Std. Error of } \\
\text { the Estimate }\end{array}$ \\
\hline 1 & $.180^{\mathrm{a}}$ & .033 & .027 & 8.89750 \\
\hline \multicolumn{5}{|c|}{ a. Predictors: (Constant), Harga Diri } \\
\hline \multicolumn{5}{|c|}{ b. Dependent Variable: Social Climber } \\
\hline
\end{tabular}

Berdasarkan tabel diatas diketahui nilai R Square sebesar 0,033. Nilai tersebut mengandung arti bahwa pengaruh harga diri $(\mathrm{X})$ terhadap perilaku social climber (Y) adalah sebesar 3,3\%. Sedangkan untuk sisanya yaitu sebesar 96,7\% perilaku social climber dipengaruhi oleh variabel lain yang tidak diteliti. 


\section{Simpulan}

Dari hasil penelitian, dapat disimpulkan bahwa terdapat hubungan positif antara variabel harga diri $(\mathrm{X})$ terhadap variabel perilaku social climber (Y). Nilai koefisien pengaruh harga diri terhadap perilaku social climber menunjukkan nilai yang positif. Sehingga dapat diinterpretasikan bahwa antara harga diri terhadap perilaku social climber saling memiliki pengaruh yang positif. Jadi semakin tinggi harga diri maka akan semakin tinggi pula perilaku social climber pada mahasiswa, meskipun pengaruhnya tergolong rendah yaitu 3,3\%. Hal tersebut terjadi karena perilaku social climber yang timbul tidak hanya dari faktor harga dirinya saja, dapat pula terjadi karena keyakinan dan komitmen yang dimiliki mahasiswa dalam berperilaku, dan juga konformitas di lingkungan sekitarnya. Maka dapat diketahui bahwa harga diri merupakan salah satu faktor atau bukan satu-satunya faktor yang dianggap mutlak mempengaruhi perilaku social climber. 


\section{DAFTAR PUSTAKA}

Artika, Marisa Disa. (2010). Social Climber Sebagai Fenomena Komunikasi (Studi Deskriptif Di Kalangan Perantau Domestik Yang Berdomestik Di Bali). Https://Www.Academia.Edu/9566801/Social_Climber_Sebagai_Fenomena_K omunikasi_Studi_Deskriptif_Di_Kalangan_Perantau_Domestik_Yang_Berdomes tik_Di_Bali Diakses Pada 13 Januari 2019.

Asytharika. (2016). Peningkatan Harga Diri (Self Esteem) Dengan Layanan Konseling Kelompok Pada Siswa Kelas Viii Di Smp Negeri 26 Bandar Lampung Tahun Pelajaran 2015/2016. Skripsi. Universitas Lampung. Fakultas Keguruan Dan Ilmu Pendidikan

Badri, Masrul \& Aziz, Azhar. (2011). Pengaruh Locus Of Control Dan Harga Diri Terhadap Motivasi Kerja Pegawai Dinas Pendidikan Kota Medan. Jurnal Analitika. Vol. 3 Nomor 1, 29-36

Bastomi, H. (2017). Menuju Bimbingan Konseling Islami. KONSELING EDUKASI : Journal Of Guidance And Counseling, 1 No. 1. https://doi.org/10.21043/konseling.v1i1.4434

Bastomi, H. (2019). Konseling Cyber: Sebuah Model Konseling Pada Konteks Masyarakat Berbasis Online. Konseling Edukasi: Journal of Guidance and Counselling, 3, No. 1.

Bastomi, H. (2020). Pemetaan Masalah Belajar Siswa SMK Negeri 3 Yogyakarta Dan Penyelesaiannya (Tinjauan Srata Kelas). KONSELING EDUKASI: Journal of Guidance And Counseling, 4 No. 1.

Fitra, Rahma. (2015). Hubungan Harga Diri Dengan Kemampuan Aktualisasi Diri Dalam Proses Belajar Metode Seven Jump Di Program Studi Ilmu Keperawatan Uin Syarif Hidayatullah Jakarta. Skripsi. Universitas Islam Negeri Syarif Hidayatullah Jakarta. Fakultas Kedokteran Dan Ilmu Kesehatan

Hays, Nicholas Adam. (2012). Social Climbing: A Contextual Approach To Understanding The Effects Of Social Hierarchy On Individual Cognition And Behavior. Dissertation. University of California. Doctor Of Philosophy In Management

Jarvis, Matt. (2018). TEORI-TEORI PSIKOLOGI: Pendekatan Modern Untuk Memahami Perilaku, Perasaan, Dan Pikiran Manusia. Bandung: Nusa Media

Jayanti, Nadia Ayu. (2015). Komunikasi Kelompok "Social Climber" Pada Kelompok Pergaulan Di Surabaya Townsquare (Sutos). Jurnal E-Komunikasi Universitas Kristen Petra Surabaya. Vol 3. No.2, 1-12 
Kembau, Agung Stefanus. (2015). The Raise Of Social Climbers \& Its Influences To Branded Items Consumption (Case Study: Manado Society, North Sulawesi). Gadjah Mada International Journal of Business. Vol. 3, No. 1

Lestari, Wahyu Ria. (2017). Para Pencari Status (Studi Tentang Perilaku Social Climber Di Kalangan Mahasiswi Di Jember). Skripsi. Universitas Jember. Fakultas Ilmu Sosial Dan Ilmu Politik

Martin, José, dkk. (2007). The Rosenberg Self-Esteem Scale: Translation And Validation In University Students. The Spanish Journal Of Psychology. Vol 10 No. 2, 458-467

Narullita, Dewi. (2017). Faktor-Faktor Yang Mempengaruhi Harga Diri Rendah Lansia Di Kabupaten Bungo. Jurnal Endurance. Vol. 2 No. 3, 354-361

Nurudin \& Muyassarah. (2017). Menilik Perempuan Sebagai Social Climber Dalam Pandangan Ekonomi Islam. Jurnal Universitas Islam Negeri (UIN) Walisongo Semarang. Vol. 12 No. 2, 225-240

Pembayun, Jaduk Gilang. (2018). Social Climbing Sebagai Aktualisasi Diri Kaum Marjinal (Studi Deskriptif Di Kalangan Remaja Jakarta Selatan). Jurnal Komunikasi Dan Kajian Media. Vol. 2 No. 2, 35-45

Permatasari, Dewi. (2017). Fenomena Social Climber Di Kalangan Mahasiswa (Studi Fenomenologi Pada Mahasiswa Di Surakarta). Skripsi. Institut Agama Islam Negeri Surakarta. Fakultas Ushuluddin Dan Dakwah

Salamiah, Nina Siti \& Dini Harpiana Suci. (2011). Hubungan Intelegensi Dan Pola Asuh Orangtua Demokrasi Dengan Harga Diri Siswa. Jurnal Analitika. Vol. 3 No. 2, 66-71

Sandha, T.P \& Sri Hartini, Naiful, F. (2012). Hubungan Antara Self Esteem Dengan Penyesuaian Diri Pada Siswa Tahun Pertama Sma Kristina Mitra Semarang. Jurnal Psikologi. Vol.1 No. 1, 47-82

Soekanto, Soerjono \& Budi Sulistyowati. (2013). Sosiologi Suatu Pengantar. Jakarta: Pt Raja Grafindo

Sugiyono. (2017). Metode Penelitian Pendidikan. Bandung: Alfabet

Wahdania, dkk. (2017). Pengaruh Efikasi Diri, Harga Diri Dan Motivasi Terhadap Hasil Belajar Matematika Peserta Didik Kelas X Sma Negeri 1 Bulupoddo Kab. Sinjai. Jurnal Matematika Dan Pembelajaran. Vol. 5 No. 1, 68-81

Wangge, Barbara D.R. \& Nurul Hartini. (2013). Hubungan Antara Penerimaan Diri Dengan Harga Diri Pada Remaja Pasca Perceraian Orangtua. Jurnal Psikologi Kepribadian Dan Sosial. Vol. 2 No. 1, 1-6 
Pengaruh Harga Diri Terhadap Perilaku ...

Widodo, Agustinus Sugeng \& Niken Titi Pratitis. (2013). Harga Diri Dan Interaksi Sosial Ditinjau Dari Status Sosial Ekonomi Orang Tua. Jurnal Psikologi Indonesia. Vol. 2 No. 2, 131 - 138 